\title{
Rocky road ahead in Senate for NSF budget increase
}

Washington

THE National Science Foundation (NSF)'s chances of obtaining a large budget increase in 1988 had been looking good, with steady progress in the House of Representatives. But all may now be lost in the Senate. There the appropriations committee is desperately hunting for cuts in total 1988 spending and it seems likely that NSF will be one of the victims.

Eric Bloch, NSF director, is maintaining a bold face in adversity. This week he is mounting a "big push" to persuade senators of the importance of boosting NSF funds and says "I don't want to be optimistic or pessimistic. Nothing is certain until the last vote is in". But it is now quite likely that NSF's budget will remain at the same level as last year.

Bloch remains convinced that support for the long-term goal of doubling NSF's budget remains solid with both the president and many congressmen still expressing enthusiasm for increased spending on science. The first step on the journey, a 16.5 per cent rise in next year's budget, had looked as though it might not be too difficult to make. Despite a few ups and downs in the House of Representatives, Bloch's argument that the nation's economic competitiveness is linked to performance in basic science had proved persuasive and the House Appropriations Committee completed deliberations with a 13.5 per cent increase for NSF.

A few of NSF's priorities were modified. Plans had been laid for thrusts in three main areas: education, including efforts to improve teaching at the pre-college level; improvement in backing for basic research and specialized research facilities; and the establishment of "science and technology centers" where the focus would be on fundamental research that contributes to economic competitiveness. The House Appropriations Committee gave particular backing to pre-college science education, at the expense of research.

Floor action before the full House of Representatives was expected to come soon after the House Appropriations Committee decision (see Nature 328, 5; 1987) but was put off until September, at least partly to try to protect the increases from any global cuts that might be arbitrarily imposed in an effort to make the whole 1988 balance. It is exactly that situation that is now being faced in the Senate.

Following a long struggle, the Senate Appropriations Committee last week could find no other way to resolve competing demands for funds from its subcommittees than to ignore its own earlier budget resolution and impose a number of across the board cuts.
The defence subcommittee was protected and the education and the labour, health and human devices subcommittees managed to win their battles for funds. One loser was the HUD-independent agencies subcommittee that is responsible for funding for NSF, the National Aeronautics and Space Administration (NASA) and the Environmental Protection Agency as well as the quite unrelated Department of Housing and Urban Development and the Veterans' Administration. Subcommittee chairman William Proxmire (Democrat, Wisconsin) showed little spirit in the budget battle.

Not much room is now left to manoeuvre in the Senate. Many of the programmes funded by the HUD-independent agencies subcommittee are those that the administration is legally committed to continue. The science programmes of NSF and NASA are far more likely to bear the brunt of the subcommittee's shortfall than are public housing or the Veterans' Administration. But NASA can argue that any cuts could lead to delay or cancellation of the space station - a project to which the United States has already given a degree of international commitment. That leaves bleak prospects for NSF. A decision on how the subcommittee will
New AIDS control recommendations

\section{Washington}

To prevent the transmission in health-care settings of the virus causing AIDS (acquired immune deficiency syndrome), the US Centers for Disease Control (CDC) recommend that blood and other body fluids "from all patients" be treated as potentially infective. The recommendations, promulgated by CDC last week and likely to be widely adopted, also urge that in cases where a health-care worker has had parenteral or mucous membrane exposure to such fluids' the source patient be tested for the presence of the AIDS virus. Although the CDC recommendations suggest special precautions to prevent the spread of AIDS virus infection, they also take some pains to demonstrate that virus transmission in health care settings is still a relatively rare event.

Joseph Palca

share out the funds is likely to come at the beginning of September.

The best chance for NSF to pull off a last minute recovery remains when House and Senate get together later in September to work out a joint 1988 budget. House backing for the NSF might well help the NSF to find a higher figure. But whether the final budget will be any larger than this year's will most likely remain doubtful right until the end.

\section{New US position threatens to jeopardize CFC agreement}

\section{London}

THE British government has apparently toughened its stand on the need to protect the Earth's ozone layer by regulating chlorofluorocarbons (CFCs), and is now urging the European Community (EC) to go into international negotiations in Montreal in early September with a position supporting a production cutback of up to 50 per cent.

But there are suggestions that some elements within the US government are trying to scuttle the international ozone agreement by introducing new initiatives into the negotiations, in spite of President Reagan's authorization for a strong US stance on the range of compounds covered and the extent of controls.

One outstanding issue revolves around the percentage of producer countries that would have to ratify the protocol before it would come into force. Some negotiators are concerned that insistence by any party on ratification by countries representing 80 per cent or more of current CFC users could give relatively small users, such as the Soviet Union, power of veto.

Disagreement over the inclusion and treatment of ozone-depleting halons also poses a potential obstacle. The United States is pushing for the inclusion of specifics on halon control, but the EC says there is not enough information yet for regulations.

Member states of the EC are asking for Single Area Status, or group treatment, for purposes of compliance with CFC reductions, and they argue that there are precedents for this move. But the United States points out that the European countries each vote separately in negotiations on the protocol, and says that insistence on Single Area Status seems to be an inequitable precondition.

Disagreements over these issues threaten to disrupt the progress achieved so far on the Vienna Convention for the Protection of the Ozone Layer, and some participants argue that it is not at all necessary to close all the loopholes as long as the ozone layer is protected.

More than thirty countries are expected to sign a protocol next month, after several years of discussions and negotiations - provided any disagreements can be overcome.
Kathy Johnston 